\title{
Preface: the structure of the Handbook
}

This Handbook brings together a collection of chapters that explores various aspects of service business with a focus on management, marketing, geography, planning, innovation and internationalisation. The Handbook deliberately brings together academics from across the social sciences and includes economists, geographers, planners, sociologists and academics from across the business school disciplines (entrepreneurship, marketing, operations). In 2007, we edited another Handbook on services that was also published by Edward Elgar (Bryson and Daniels, 2007). This brought together a very different collection of scholars and had a very different structure and title from this new Handbook. It was entitled The Handbook of Service Industries and was divided into five parts: conceptual perspectives on services, the development of service economies, trading services: from local to global production, services, technology and innovation, and service employment: embodied and emotional labour.

This new Handbook is not intended to replace our 2007 book, but to provide an alternative account of the shift towards service-led or service-dominated societies. The difference from our earlier Handbook is the emphasis that is placed in the new Handbook on service business or the activities and processes that lead to the production and consumption of services. It was not our intention to cover all aspects of services, as this would have led to the production of a very large volume. We were also aware that two specialist Handbooks that focused on services had been published since our 2007 collection. In 2010, Maglio et al. produced their Handbook of Service Science that provides an interdisciplinary approach to studying, improving, creating and innovating services. This collection was a call for the development of a new science of services that would lead to the development of a new set of methodologies and theories. In 2010 Gallouj and Djellal produced The Handbook of Innovation and Services: A Multi-disciplinary Approach. The Gallouj and Djellal Handbook focuses on understanding the role of innovation in all types of services.

It is interesting that all four Handbooks that focus on services are multi-disciplinary, but each has a very different objective. Service research is to be found across the social sciences and even in the discipline of engineering (Maglio et al., 2010). Our new Handbook is divided into four parts. The first part provides four disciplinary perspectives on services. This includes accounts from economics (Chapter 2), economic geography (Chapter 3) and service science (Chapter 4). Unusually, it also contains a chapter written by a practitioner (Chapter 5). In this chapter, Steve Hollis, a former partner at KPMG, provides a fascinating insider account of the challenges facing the Big 4 accountancy firms as they respond to new forms of competition. In the second part the focus is on exploring services and core business processes. This includes six chapters that explore sustainability and services (Chapter 6), service consumption (Chapter 7), the creation of value and its capture through the provision of services (Chapter 8), measuring new firm formation (Chapter 9), the growth of information-intensive services in the US (Chapter 10) and a detailed account of services as experiences (Chapter 11). In part III the focus 


\section{xiv Handbook of service business}

is on understanding some of the management aspects of service businesses. This includes an analysis of the organisation of service businesses (Chapter 12), the management of creative employees (Chapter 13), the globalisation and internationalisation of services (Chapters 14 and 15), innovation in professional service firms (Chapter 16) and client relationship management (Chapter 17). The final part provides a series of industry case studies. It was not our intention to provide case studies of all service sectors. This part contains four chapters that explore logistics (Chapter 18), creative and cultural industries (Chapter 19), tourism (Chapter 20) and the growth of producer services in China (Chapter 21). In this part there is a mix of sector and country case studies. 